\title{
Pengembangan Sistem Informasi Rute Bus Transjakarta yang Terintegrasi Pada Google Maps Menggunakan Metode Rapid Application Development
}

\author{
Hendarman Lubis ${ }^{1}$, Susi Rianti ${ }^{2}$ dan Esrayanti $^{3}$ \\ Jurusan Teknik Informatika, FakultasTeknik, UniversitasBhayangkara Jakarta Raya, ${ }^{1,2,3}$ \\ E-mail :hendarman.lubisf@dsn.ubharajaya.ac.id ${ }^{1}$, susi.rianti@dsn.ubharajaya.ac.id ${ }^{2}$, \\ esrayantipandiangan8@gmail.com ${ }^{3}$
}

\begin{abstract}
Pengembangan sistem informasi rute bus transjakarta yang terintegrasi dengan google maps dalam bentuk aplikasi berbasis android bertujuan untuk meningkatkan informasi masyarakat dalam penggunaan bus transjakarta, mempermudah masyarakat umum dalam pencarian rute dan peta transit bus transjakarta. Sistem informasi rute bus transjakarta yang terintegrasi dengan google maps menjadi solusi atas kelemahan pada sistem yang sebelumnya sudah dibangun. Metode pengumpulan data yang digunakan dalam penelitian ini, yaitu observasi, wawancara, studi pustaka, studi literatur, kuisioner, dan metode pengembangan sistem. Metode pengembangan sistem yang digunakan dalam pengembangan sistem informasi rute bus transjakarta ini adalah metode RAD (Rapid Application Development). Pengujian fungsional sistem dilakukan menggunakan black box testing. Dengan dilakukannya pengembangan sistem informasi rute bus transjakarta yang terintegrasi dengan google maps, masyarakat umum dapat dengan mudah mendapatkan informasi rute bus transjakarta dan informasi peta transit bus transjakarta.
\end{abstract}

Kata kunci: Sistem Informasi, Rute Bus Transjakarta, Rapid Aplication Development, Android

\section{PENDAHULUAN}

Masyarakat dikota Jakarta menghadapi permasalahan pelik, yaitu masalah transportasi yang semakin hari semakin rumit yang diakibatkan oleh pertambahan ruas jalan tidak sepadan dengan pertambahan jumlah kendaraan setiap harinya. Hal ini mengakibatkan macet yang yang semakin parah terutama pada jam kerja. Berbagai cara telah ditempuh oleh pementah daerah kota Jakarta, seperti memberlakukan tree in one pada jam kerja atau office hour. Pemerintah propinsi Jakarta juga menyediakan transportasi umum Transportasi umum yang murah, cepat seperti busway. Busway atau disebut juga dengan dikelola oleh Transjakarta berada pada satu jalur khusus, dengan tujuan untuk meminimalkan angka kemacetan sekaligus memindahkan cara transprortasi warga Jakarta dan sekitarnya dari mobil pribadi ke angkutan masal, dan menurunkan angka polusi udara yang disebabkan oleh asap kendaraan bermotor. PT. Transportasi Jakarta yang bertempat di Jl. Mayjen Sutoyo No.1, Kel. Kebon Pala, Kec. Makasar, RT.5/RW.5 Jakarta Timur, DKI Jakarta.

Adapun data pengguna bus Transjakarta tiga tahun terakhir dapat di lihat pada tabel di bawah ini. 
Tabel 1.1 Jumlah Penumpang Bus Transjakarta

\begin{tabular}{|c|c|l|}
\hline Tahun & Total & \multicolumn{1}{|c|}{$\begin{array}{c}\text { Persentase } \\
(\%)\end{array}$} \\
\hline 2014 & 111.969 .896 & 33,06 \\
\hline 2015 & 102.950 .384 & 30,40 \\
\hline 2016 & 123.706 .857 & 36,53 \\
\hline
\end{tabular}

Sumber : PT Transportasi Jakarta

Jika di lihat pada tahun 2016 jumlah penumpang semakin meningkat $36,53 \%$. hal ini menunjukkan bahwa pengguna bus Transjakarta cukup diminati oleh masyarakat Indonesia.

Sementara jika di bandingkan dengan kendaraan Pribadi yang cukup banyak di Jakarta akan menyebabkan tingkat kemacetan yang semakin buruk. Hal ini dapat di lihat pada tabel 1.2 bagaimana perbandingan tingkat pengguna kendaraan pribadi dan angkutan umum di Jakarta dan sekitarnya.

Tabel 1.2 Data Pengguna Kedaraan Pribadi dan Angkutan Umum Sejabodetabek

\begin{tabular}{|l|l|l|}
\hline Tahun & $\begin{array}{l}\text { Kendaraan } \\
\text { Pribadi }\end{array}$ & $\begin{array}{l}\text { Angkutan } \\
\text { Umum }\end{array}$ \\
\hline 2014 & 9.902 .917 & 112.724 \\
\hline 2015 & 11.091 .447 & 126.250 \\
\hline 2016 & 12.422 .420 & 141.400 \\
\hline Total & 33.416 .784 & 380.374 \\
\hline
\end{tabular}

Sumber: bps DKI Jakarta

Dari tabel di atas telihat jelas bagaimana perbandingan jumlah pengguna kendaraan pribadi dengan transportasi umum yang cukup berbanding jauh dengan selisih 33.036.410 pengguna. Dari selisih inilah yang juga dapat memper-parah tingkat kemacetan di Ibu kota. Untuk itu harapan masayarakat pada Pemprov DKI (Daerah Khusus Ibukota) Jakarta lebih berinovatif untuk mencari solusi dalam mengatasi tingkat kemacetan di Ibu kota karena salah satu akibatnya dalam pembangunan proyek infrastruktur.

Saat ini dirasa bahwa efektifitas busway yang diharapkan berperan memperlancar lalu lintas, masih belum terealisasikan. Hal ini berdampak pada anggapan baru bahwa busway menjadi penyebab kemacetan. Selain digunakannya jalur busway oleh kendaraan pribadi, sebagian besar masyarakat belum sepenuhnya berahli ke busway, melainkan masih tertahan menggunakan kendaraan pribadi. Disamping itu, kondisi manajemen internal pada busway seperti jumlah armada yang kurang dan perhitungan headway yang kurang akurat berpengaruh pada proses pendistribusian bus. Dampaknya dapat terlihat dengan tidak tercapainya target jarak waktu antar armada di lintasan busway dan penumpukan penumpang di halte terutama pada jam sibuk.

Berdasarkan analisa penulis dari aplikasi TransJakarta Busway, penulis melihat begitu banyak kelemahan dari aplikasi ini, dari hasil riset yang saya temukan pengguna aplikasi ini masih memberikan keluhan seperti belum tersedianya beberapa rute halte dan koridor dengan rute hate baru yang belum terdaftar pada aplikasi ini. Di samping itu, para pengguna aplikasi juga mengharapkan untuk pengembangan yang lebih, seperti pada menu bus Tracking yang tidak berfungsi dengan baik guna untuk mengetahui posisi dimana bus itu berada. Dengan adanya menu ini pengguna tidak merasa jenuh dalam menunggu kedatangan bus apalagi di jam-jam sibuk seperti pagi 
dan sore hari. Pengguna juga dapat memonitoring kilometer bus tersebut berada dan mengetahui berapa jumlah bus keluarmasuk halte per-hari nya.

Umumnya masyarakat pengguna bus Transjakarta masih banyak yang belum mengerti bagaimana proses transit di berbagai titik-titik halte bus Transjakarta Sejabodetabek. Seperti yang dialami oleh beberapa pengguna masih kurang mengerti dimana saja titik pentransitan halte bus. Seperti pada aplikasi TransJakarta Busway hanya berupa teks bacaan saja. Untuk ini penulis memiliki ide untuk menambah rute peta pada aplikasi selanjutnya untuk mengetahui jalur bus berada.

Sementara pengguna Internet di Indonesia tahun 2016 menurut situs Merdeka.com hasil survey yang dilakukan oleh Assosiasi Penyelenggara Jaringan Internet Indonesia (APJII) mengatakan bahwa lebih dari setengah penduduk Indonesia telah terhubung ke Internet. Survey yang dilakukan sepanjang tahun 2016 menemukan bahwa 132,7 juta orang Indonesia telah terhubung ke internet. Adapun total penduduk Indonesia sebanyak 256,2 juta orang. Hal ini mengindikasikan kenaikan 51,8 \% di bandingan jumlah pengguna internet pada 2014 hanya 88 juta orang pengguna internet.

Android merupakan sistem operasi untuk ponsel berbasis Linux yang berflatform terbuka bagi para pengembang guna menciptakan aplikasi yang dirancangnya. Sistem Android pada dasarnya berisikan tumpukan dari beberapa lapisan agar perangkat keras dapat berinteraksi dengan penggunanya.[1]

Pencarian informasi bus hanya berdasarkan lokasi awal dan akhir yang dipilih oleh user sementara dari segi design masih belum diimbangi dengan perancangan seperti bahasa, huruf dan warna tema.Sistem informasi yang dibangun bisa membantu para pengguna angkutan umum yang mengalami kesulitan dalam mencari rute bus Mayasari Bakti.[2.]

Dalam pengujian aplikasi koneksi internet dan GPS dapat berjalan dengan baik ketika koneksi internet stabil dan GPS. Aplikasi ini berhasil dibangun sebagai media pencarian rute angkutan umum dan pengujian menu-menu pada aplikasi dapat berjalan dengan baik.[3]

Tujuan penelitian ini adalah meningkatkan informasi masyarat dalam pencarian rute bus Transjakarta.umum dalam pencarian rute bus Teransjakarta, dan untuk mempermudah proses transit.

\section{Metodelogi Penelitian}

\subsection{Pengembangan}

Menurut Kamus Besar Bahasa Indonesia (KBBI) Pengembangan atau pengembang atau kata dasar kembang adalah proses, cara, perbuatan mengembangkan: pemerintah selalu berusaha dalam pembangunan secara bertahap dan teratur yang menjurus ke sasaran yang dikehendaki. Dari sisi Bahasa pengembangan adalah upaya meningkatkan mutu bahasa agar dapat dipakai untuk berbagai keperluan dalam kehidupan masyarakat modern sementara dari sisi Masyarakat pengembangan adalah proses kegiatan bersama yang dilakukan oleh penghuni suatu daerah untuk memenuhi kebutuhannya. 


\subsection{RUTE}

Menurut Kamus Besar Bahasa Indonesia (KBBI) Rute atau Nomina (kata benda) terdiri atas 3 pengertian di antaranya:

1. Jarak atau arah yang harus (ditempu, dilalui): menempuh rute itu dalam waktu 12 jam;

2. Jalan yang di tempuh (dilalui); reli itu akan menempuh rute Jakarta-Surabaya;

3. Jalur angkutan yang berhubungan dua tempat.

\subsection{Transjakarta}

Transjakarta umumnya disebut Busway adalah sistem transportasi $\underline{B u}$ Rapid Transit (BRT) pertama di Asia Tenggara dan Selatan, yang beroperasi sejak tahun 2004 di Jakarta, Indonesia. Sistem ini didesain berdasarkan sistem $\underline{\text { TransMilenio yang sukses di Bogota, }}$ Kolombia. Transjakarta dirancang sebagai moda transportasi massal pendukung aktivitas ibu kota yang sangat padat. Transjakarta merupakan sistem BRT dengan jalur lintasan terpanjang di dunia (208 km), serta memiliki 242 stasiun BRT (sebelumnya disebut halte) yang tersebar dalam 13 koridor (jalur), yang awalnya beroperasi dari 05.00 - 22.00 $\underline{\mathrm{WIB}}$, dan kini beroperasi 24 jam di sebagian koridornya.

Transjakarta dioperasikan oleh PT Transportasi Jakarta. Jumlah tenaga kerja yang terlibat dalam operasional Transjakarta (Pramudi, petugas bus, petugas stasiun BRT, dan petugas kebersihan) sekitar 6.000 orang. Jumlah rata-rata harian pengguna Transjakarta diprediksikan sekitar 350.000 orang. Sedangkan pada tahun 2012, Jumlah pengguna Transjakarta mencapai 109.983.609 orang.

\subsection{Android Studio}

Menurut "Android Studio merupakan lingkungan pengembangan
Andriod baru yang berdasarkan intelliJ IDEA. Android Studio ini mirip cara kerjanya dengan Eclipse $+A D T$ plugin, Android studio menyediakan alat pengemangan android yang terintegrasi dalam pengembangan dan debugging program"[4].

\subsubsection{ArsitekturAndroid}

Secara garis besar Arsitektur Android dapat dijelaskan dan digambarkan sebagai berikut:

1. Applications dan Widgets

Aplplications dan Widgets adalah layar dimana kita berhubungan dengan aplikasi, dimana bisanya kita download aplikasi dan baru kita jalankan. Semua aplikasi ditulis menggunakan bahasa pemrograman java

\section{Applications Frameworks} Android adalah "Open Development Platform" dimana para pengembang membangun aplikasi yang bagus dan inovatif dan di jalankan di sistem operasi android, dengan layar aplikasi di rancang dan dibuat seperti content-provider yang berupa sms dan panggilan telepon. Komponen-komponen yang termasuk di dalam Applications Frameworks sendiri adalah sebagai berikut:
a. Views
b. Content Provider
c. Resource Manager
d. Natificatios Manager
e. Activity Manager

\section{Libraries}

Libraries adalah layar dimana fitur-fitur android berada, biasanya para pembuat aplikasi mengakses libraries untuk menjalankan aplikasinya. Berjalan di atar kernel, layar ini meliputi bebrbagai library C/C++ inti seperti Libc dan SSL, serta: 
a. Libraries media untuk pemutaran media audio dan video

b. Libraries untuk manajemen tampilan

c. Libraries Graphics mencakup SGL dan OpenGL untuk 2D dan 3D

d. Libraries SQLite untuk dukungan database

e. Libraries SSL dan WebKit terintegrasi dengan web browser dan security

f. Libraries LiveWebcore mencakup modern web browser dengan ingine embeded web view

g. Libraries 3D yang mencakup implementasi OpenGL ES 1.0 API's

\section{Android Run Time}

Layer yang membuat aplikasi android dapat dijalankan dimana dalam prosesnya menggunakan implementasi Linux. Dalvik Virtual Machine (DVM) merupakan mesin yang membentuk dasar kerangka aplikasi android. Di dalam android Real Time di bagi menjadi dua bagian yaitu:

a. Core Libraries

Aplikasi android dibangun dalam bahasa java, sementara Dalvik sebagai virtual mesinnya bukan Virtual Machine Java, sehingga diperlukan sebuah libraries yang berfungsi untuk menterjemah bahasa java/c yang ditangani oleh Core Libraries

b. Dalvik Virtual Machine

Virtual mesin berbasis register yang dioptimalkan untuk menjalankan fungsi-fungsi secraa efesien, dimana merupakam pengembangan yang mampu membuat linux kernel untuk melakukan threading dan manajemen tingkat rendah

\section{Linux Kernel}

Linux kernel adalah layer dimana inti dari operating sistem dari Android. Berisi file-file system yang mengatur sistem processing, memory, resource, drivers, dan sistem-sistem operasi android lainnya.

\subsubsection{Komponen Android}

Terdapat 6 jenis komponen aplikasi

Android diantaranya sebagai berikut:

1. Activities

Suatu activity akan menyajikan user interface (UI) kepada pengguna, sehingga pengguna dapat melakukan interaksi. Sebuah aplikasi android hanya memiliki satu activity, tetapi memiliki banyak activity tergantung pada tujuan aplikasi dan desain dari aplikasi nya. Untuk pindah dari satu activity ke activity lain kita dapat melakukannya dengan satu even. Secara hirarki sebuah windows activity dinyatakan dengan method Activity.setContentView().ContenView adalah objek yang berada pada root hirarki

2. Service

Service tidak memiliki Graphic User Interface (GUI), tetapi service berjalan secara background. Service dijalankan pada thread utama dari proses aplikasi.

3. Broadcast Receiver

Broadcast Receiver berfungsi menerima dan bereaksi untuk menyampaikan notifikasi. Aplikasi juga dapat menginisiasi broadcast misalnya memberikan informasi pada aplikasi lain bahwa ada data yang telah diunduh ke perangkat dan siap untuk digunakan.

Broadcast receiver tidak memiliki user interface (UI), tetapi memiliki sebuah activity untuk merespon informasi yang diterima, atau menggunakan Notification Manager untuk memberitahu ke pengguna. 
4. Content provider

Content provider membuat kumpulan aplikasi data secara spesifik sehingga bisa digunakan oleh aplikasi lain. Data disimpan dalam file sistem seperti database SQLite. Content provider menyediakan cara untuk mengakses data yang dibutuhkan oleh suatu activity contoh aplikasi untuk peta (map), aplikasi untuk mengakse data kontak dan navigasi.

\subsection{Java}

Java adalah bahasa yang dapat dijalankan disembarang platfrom, diberagam lingkungan internet, consumer electronic products, dan computer applications. Java merupakan karya Sun Microsystem Inc, resmi dirilis pada November 1995. Pada consumer electronic product, hanya sejumlah kecil bagian bahasa yang digunakan. Masing-masing edisi berisi Java 2 Software Development Kit (SDK) untuk mengembangkan aplikasi dan Java 2 Runtime Envirotment (JRE) untuk menjalankan aplikasi.[5]

\subsection{Java Development Kit (JDK)}

Java Development Kit (JDK) adalah perangkat pengembangan aplikasi Java, aplikasi ini sangat diperlukan untuk membuat aplikasi pada android. Java Development Kit (JDK) berisi sekumpulan kakas, utilitas, dan dokumentasi serta kode applet pada baris perintah (command-line tool) untuk menciptakan program Java.[6]

\subsection{PHP}

PHP (Hypertext Prepocessor) adalah bahasa script yang dapat ditanamkan atau disisipkan ke dalam HTML (HyperText Markup Language). PHP banyak dipakai untuk membuat program situs web dinamis. PHP sering juga digunakan untuk membangun sebuah CMS (Content Management System)".
PHP adalah bahasa pemrograman script server-side yang didesain untuk pengembangan web. Disebut bahasa pemrograman server side karena PHP diproses pada komputer server. Hal ini berbeda dibandingkan dengan bahasa pemrograman clien-side seperti Java Script yang diproses pada web browser (client).[7]

\subsection{Dreamweaver}

Dreamweaver merupakan software aplikasi yang digunakan sebagai HTML (HyperText Markup Language) editor profesional untuk mendesain web secara visual. Aplikasi ini juga yang biasa dikenal denga istilah WYSIWYG (What You See Is What You Get), yang intinya bahwa anda tidak harus berurusan dengan tag-tag HTML untuk membuat suatu situs. Selain itu Dreamweaver juga memberikan keleluasaan kepada anda untuk menggunakannya sebagai media penulisan bahasa pemrograman web[8].

\subsection{MySQL}

MySQL (My Structured Query Language) adalah sistem manajemen database SQL yang bersifat Open Source. Sistem database MySQL mendukung beberapa fitur seperti multiihread, multi user dan SQL database manajement system (DBMS). Database ini dibuat untuk keperluan sistem database yang cepat, handal dan mudah digunakan [7].

\subsection{Website}

Website merupakan kumpulan dari halaman-halaman yangb berhubungan dengan file-file lain yang yang saling terkait. Dalam sebuah website terdapat satu halaman yang di kenal dengan sebutan home-page. Homepage adalah sebuah halaman yang pertama kali dilihat ketika seseorang mengunjungi sebuah website. [9]. 


\subsection{Google Maps}

Google maps merupakan sebuah layanna gratis yang diberikan oleh google dan sangat populer. Google maps adalah suatu peta dunia yang dapat kita gunakan untuk dapat melihat suatu daerah. Google maps juga peta digital yang bisa dilihat hanya menggunakan suatu browser. Kita dapat menambahkan fitur Google maps dalam suatu aplikasi atau web yang kita buat atau pada blog kita yang berbayar maupun yang gratis sekalipun google maps API (Application Programming Interface). Google maps API adalah suatu library yang berbentuk javascript dimana kita dapat mengubah dan menambah variabel-variabel tertentu sehingga bisa dibuat dengan keinginan kita.

\subsection{Metode Rapid Application Development \\ Metode \\ Rapid \\ Application}

Development (RAD) adalah model proses pengembangan perangkat lunak yang bersifat inkremental terutama untuk waktu pengerjaan yang pendek. Model RAD adalah adaptasi dari model air terjun versi kecepatan tinggi dengan menggunakan model ait terjun untuk pengembangan setiap komponen perangkat lunak[10].

Jika kebutuhan perangkat lunak dipahami dengan baik dan lingkup perangkat lunak dibatasi dengan baik sehingga tim dapat menyelesaikan pembuatan perangkat lunak dengan waktu yang singkat. Model RAD membagi tim pengembang menjadi beberapa tim untuk mengerjakan beberapa komponen masingmasing tim pengerjaan dapat dilakukan secara sejajar. Berikut adalah gambar model RAD:

Berikut penjelasan dari model RAD di atas, sabagai berikut:

1. Pemodelan bisnis
Pemodelan yang dilakukan untuk memodelkan fungsi bisnis untuk mengetahui informasi apa saja yang terkait proses bisnis, informasi apa saja yang harus dibuat, siapa yang harus membuat informasi, bagaimana alur informasi nya, proses apa saja yang terkait informasi tersebut.

2. Pemodelan data

Memodelkan data apa saja yang dibutuhkan berdasarkan pemodelan bisnis dan mendefinisikan atributatributnya beserta dengan data-data lain

3. Pemodelan proses

Mengimplementasikan fungsi bisnis yang sudah didefinisikan terkait dengan pendefinisian data

4. Pembuatan aplikasi

Mengimplementasikan pemodelan proses dan data menjadi program. Model RAD sangat menganjurkan pemakaian komponen yang sudah ada jika dimungkinkan

5. Pengujian dan Pergantian

Menguji komponen-komponen yang dibuat. Jika sudah teruji maka tim pengembang komponen dapat beranjak untuk mengembangkan komponen berikutnya

Dari dasar konsep model RAD ini munculkan model-model yang berdasarkan atau memodifikasi model RAD sebagai berikut:

1. Pengembangan Perangkat Lunak "Tangkas" (Angile Software) dimana interaksi antar anggota tim dan pelanggan dianggap sebagai hal yang penting dari perangkat ataupun proses pengembangan perangkat lunak. Hal ini ditujukan agar pengembangan bersifat sangat tangkas dalam menangani perubahan yang terjadi. Contoh pengembangan perangkat lunak "tangkas" adalah scrum dan pemrograman ekstrim. 
a. Pengembangan Scrum (semua tim) Semua tim yang terlibat di dalam proyek bekerja secara overlapping (tumpang tindih) sesuai dengan kebutuhan sumber daya pada proyek perangkat lunak agar dpaat meningkatkan kecepatan pengembangam dan fleksibilitas. Peranan setiap tim di dalam model scrum telah ditentukan.

b. Pengembangan Pemrograman Ekstrim (Extreme Programming)

Mengijinkan tim pengembang untuk berkomunikasi langsung dengan pelanggang (customer) atau user maupun sesama pembuat program (programmer). Ciri khas dari model ini adalah komunikasi yang dilakukan setiap hari atau setiap ditemukan hal-hal baru yang kurang jelas. Model ini sangat mengandalkan adanya umpan balik (feedback) sehingga dibutuhkan anggota-anggota tim yang berkualitas.

\section{Hasil dan Pembahasan \\ 3.1 Objek Penelitian}

Penelitian ini dilakukan untuk merancang suatu sistem informasi rute bus Transjakarta berbasis android, yang nanti sistemnya berupa sebuah aplikasi mobile phone berbasis android yang dapat di digunakan oleh masyarakat Jakarta dan sekitarnya. Dalam aplikasi ini masyarakat memilih lokasi halte awal dan halte tujuan, dan dapat melihat halte transit dimana saja dan akan ditujukan pada google maps yang nantinya kita dapat melihat posisi bus berada dan kilometer setiap haltenya terdapat. Objek penelitian pada skripsis ini adalah PT. Transportasi Jakarta yang bertempat di J1. Mayjen Sutoyo No.1, Kel. Kebon Pala, Kec. Makasar, RT.5/RW.5 Jakarta Timur, Daerah Khusus Ibu Jakarta.
Transjakarta memulai operasinya pada 15 Januari 2004, ditandai dengan peresmian Koridor 1, dengan tujuan memberikan jasa angkutan yang lebih cepat, nyaman, dan terjangkau bagi warga Jakarta. Sejak awal pengoperasian Transjakarta, harga tiket ditetapkan untuk disubsidi oleh pemerintah daerah. Dalam rangka sosialisasi dan pengenalan angkutan massal ini kepada masyarakat, pada 2 minggu pertama pengoperasiannya (15-30 Januari 2004) pengguna Transjakarta tidak dikenakan tarif. Mulai 1 Februari 2004, tarif Transjakarta mulai diberlakukan seharga Rp2000. Pada tahun 2012, Dinas Perhubungan DKI Jakarta memutuskan untuk menaikkan tarif Transjakarta seharga Rp.3.500.

Pada tahun 2004 TransJakarta diputuskan berbentuk Badan Pengelola (BP) Transjakarta berdasarkan Keputusan Gubernur No. 110/2013 dimana:

1. TransJakarta dikelola secara nonstruktural

2. Menggunakan dana transfer

3. Anggaran yang fleksibel

4. Pendapatan yang dapat di setor

5. Bertanggungjawab langsung ke Gubernur

Pada 04 Mei 2006, Gubernur DKI Sutiyoso mengubah Badan Pengelolah (BP) TransJakarta menjadi Badan Layanan Umum (BLU). TransJakarta yang adalah Unit Pelaksana Teknis (UPT) di bawah Dinas Perhubungan (Dishub) Provinsi DKI Jakarta. Hal ini diatur dalam Peraturan Gubernur (Pergub) DKI No. 48 Tahun 2006.

\subsubsection{Visi, Misi Dan Slogan PT Transportasi Jakarta \\ Adapun visi, misi dan slogan perusahaan yang dijadikan sebagai suatu pedoman adalah:}




\section{Visi}

Visi dari PT. Transportasi Jakarta adalah menjadi perusahaan transportasi berkelas dunia yang menjadi pilihan utama bagi mobilitas masyarakat di DKI Jakarta

\section{Misi}

1. Memberikan solusi untuk mengatasi masalah kemacetan dan mobilitas masyarakat di DKI Jakarta

2. Menjadi perusahaan transportasi publik yang bekelas dunia yang sehat dan berkontribusi positif bagi Pemegang Saham dan Pemangku Kepentingan

3. Membangun insan yang profesional, pedulu dan penuh integritas dengan semangat pelayanan dan gotong royong (teamwork) yang kuat

4. Menerapkan budaya kerja yang mengutamakan keandalan pelayanan (service excellence) dan kepuasan pelanggan (customer satisfaction)

\section{Slogan}

Slogan PT Transportasi Jakarta adalah MANTAP, yaitu:

1. M : Melayani dengan hati yang peduli

2. A : Amanah mewujudkan visi dan misi Transjakarta

3. N : Nilai kerja kami adalah kepuasan pelanggan

4. T : Tanggap menjadi solusi bagi pelanggan

5. A : Aktif terus menerus mengingkatkan keandalan pelayanan

6. P : Profesonal dalam karya, karsa, dan kata.

\subsubsection{Tujuan PT. Transportasi Jakarta}

Sejumlah perjalanan membutuhkan waktu yang lama dan jarak yang jauh, sehingga tidak mungkin dilakukan dengan berjalan kaki atau naik sepeda. Pada sejumlah kota megapolitan, lalu lintas semakin penuh dengan kendaraan pribadi dan truk sehingga memperlambat jalannya bus kota dan angkutan umum lainnya. Oleh karena itu, Pemerintah Daerah ikut campur tangan dalam memperbaiki sistem angkutan umum, yaitu dengan menyediakan layanan Bus Trapid Transit (BRT). Sistem BRT Transjakarta merupakan angkutan umum massal yang dapat memindahkan jutaan orang dengan cepat dan nyaman dengan lebih sedikit bahan bakar dan ruang daripada yang diperlukan mobil.

Karena tujuan yang relatif rendah dan waktu pembangunan yang cepat, sistem BRT terbukti dapat mengejar pertumbuhan kota metropolitan dan motorisasi yang pesat sementara pada saat yang sama menyediakan layanan yang sebanding dengan kereta bawah tanah.

\subsubsection{Tugas PT. Transportasi Jakarta}

Untuk mencapai tujuan tersebut Transjakarta didukung oleh tiga pilar yang merupakan tida bidang tugasnya. Ketida bidang tugas ini adalah pertumbuhan perilaku berlalu lintas transjakarta, keadilan bertransportasi transjakarta dan penyandang disabilitas. Ketiga perlu di integrasi agar tujuan menciptakan Jakarta yang bebas kemacetan dan dapat dicapai secara efektif dan efisien.

\subsection{Analisis Kebutuhan Sistem}

Dari hasil survey yang dilakukan penulis, maka bisa disimpulkan adalah setuju untuk mengembangkan suatu program baru.

\subsection{Perancangan Sistem Usulan}

Sistem ini nantinya akan menghasilkan suatu perancangan yang dapat membantu pelayanan bus Transjakarta dalam memenuhi kebutuhan pengguna. Sistem informasi yang di usulkan merupakan langkah untuk lebih mengefektifkan dan mengefesiensikan sistem yang sedang berjalan. 
Para pengguna bus akan lebih mudah mengerti dengan adanya sistem ini, dimana pada sistem nantinya akan menjelaskan lebih detail posisi bus dan jarak bus ke halte.

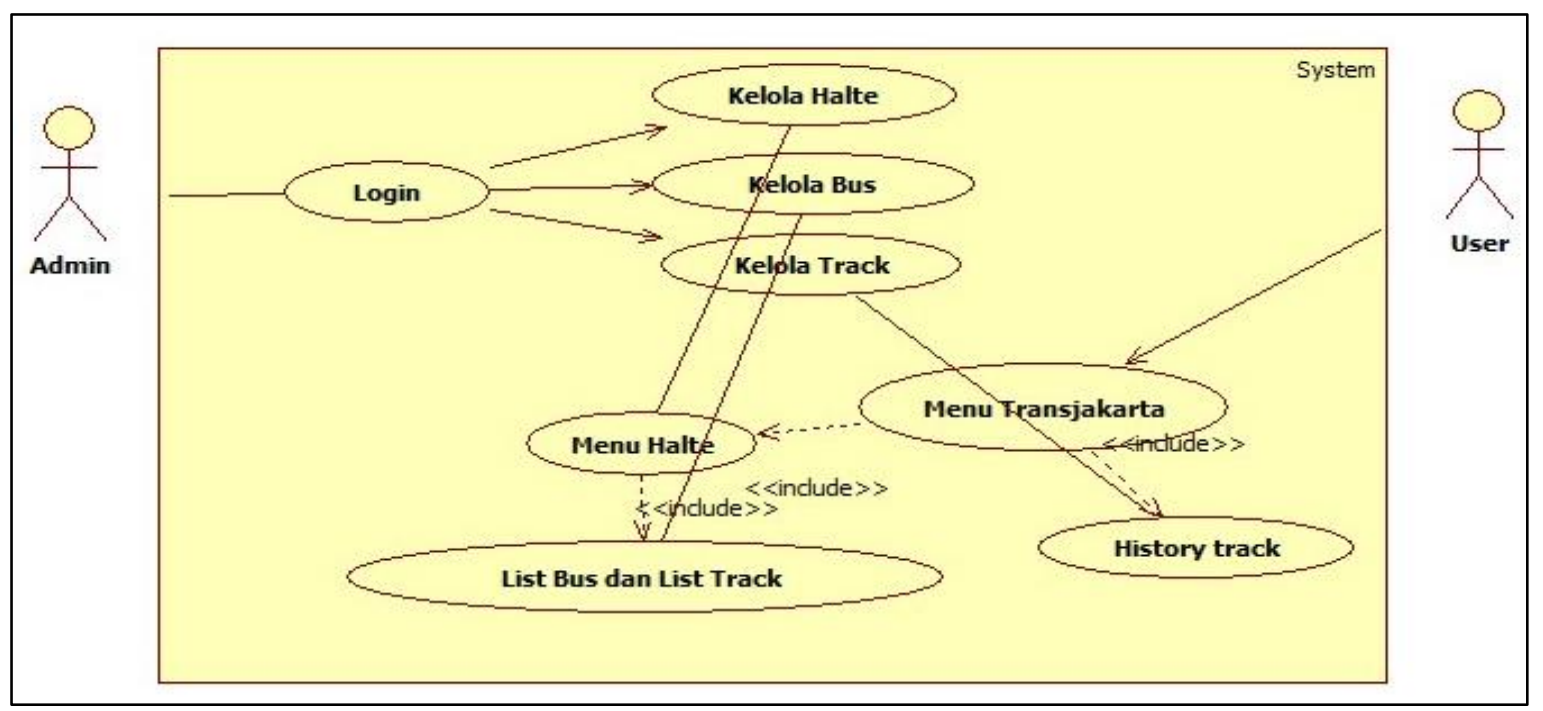

Gambar 3.3. Use Case diagram

\subsubsection{Activity Diagram Kelola Halte}

Berikut di bawah ini merupakan activity diagram kelola halte, pada activity diagram ini langkah pertama yang di lakukan Admin adalah membuka menu utama web server, kemudian masuk ke menu bus, setelah itu admin menginput from input data dan data yang sudah di input akan di simpan dan di proses pada database, kemudian admin juga bisa mengedit dan menghapus data yang sudah di input sebelumnya.

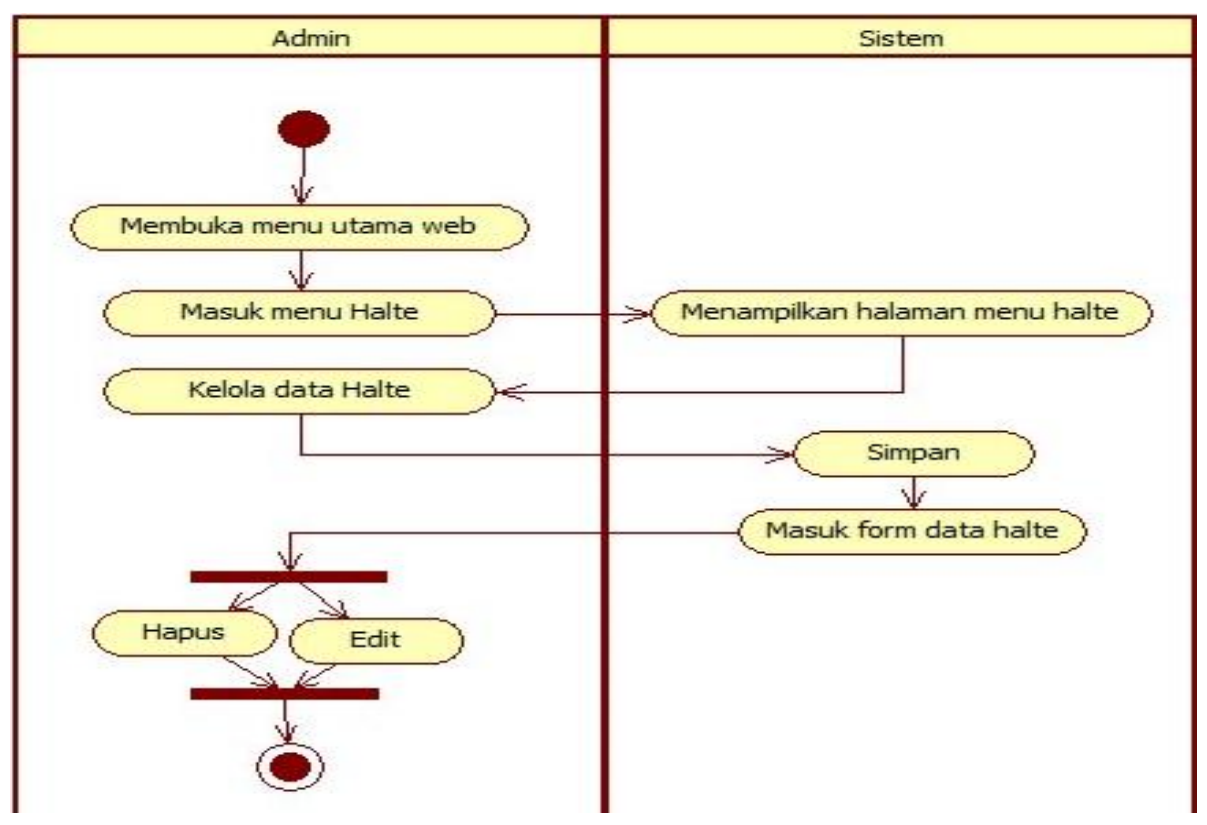

Gambar 3.3.1 Activity Diagram Kelola Halte 


\subsubsection{Activity Diagram Kelola Bus}

Berikut di bawah ini merupakan activity diagram kelola bus, pada activity diagram ini langkah pertama yang di lakukan Admin adalah membuka menu utama web server, kemudian masuk ke menu bus, setelah itu admin menginput from input data dan data yang sudah di input akan di simpan dan di proses pada database, kemudian admin juga bisa mengedit dan menghapus data yang sudah di input sebelumnya.

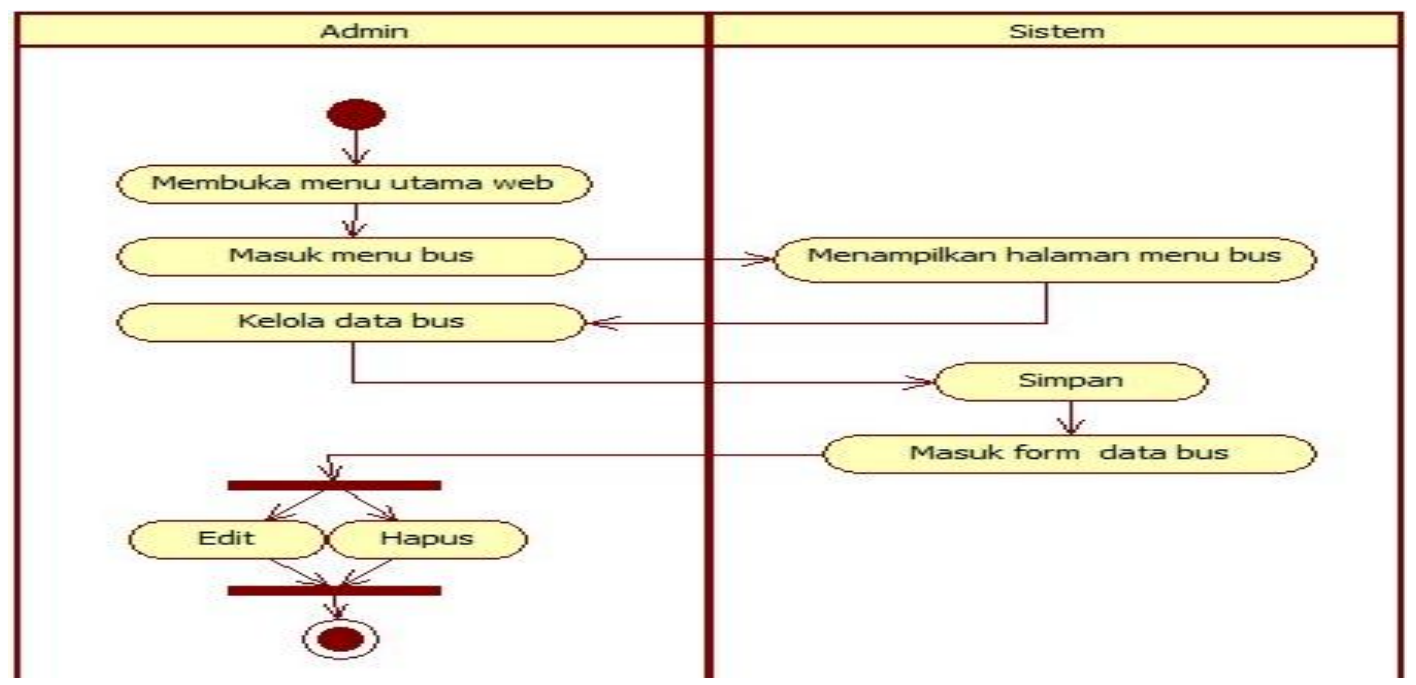

Gambar 3.3.2. Activity Diagram Kelola Bus

\subsubsection{Activity Diagram Kelola Track}

Berikut di bawah ini merupakan activity diagram kelola track, pada activity diagram ini langkah pertama yang di lakukan Admin adalah membuka menu utama web server, kemudian masuk ke menu track, setelah itu admin menginput from input data dan data yang sudah di input akan di simpan dan di proses pada database, kemudian admin juga bisa mengedit dan menghapus data yang sudah di input sebelumnya.

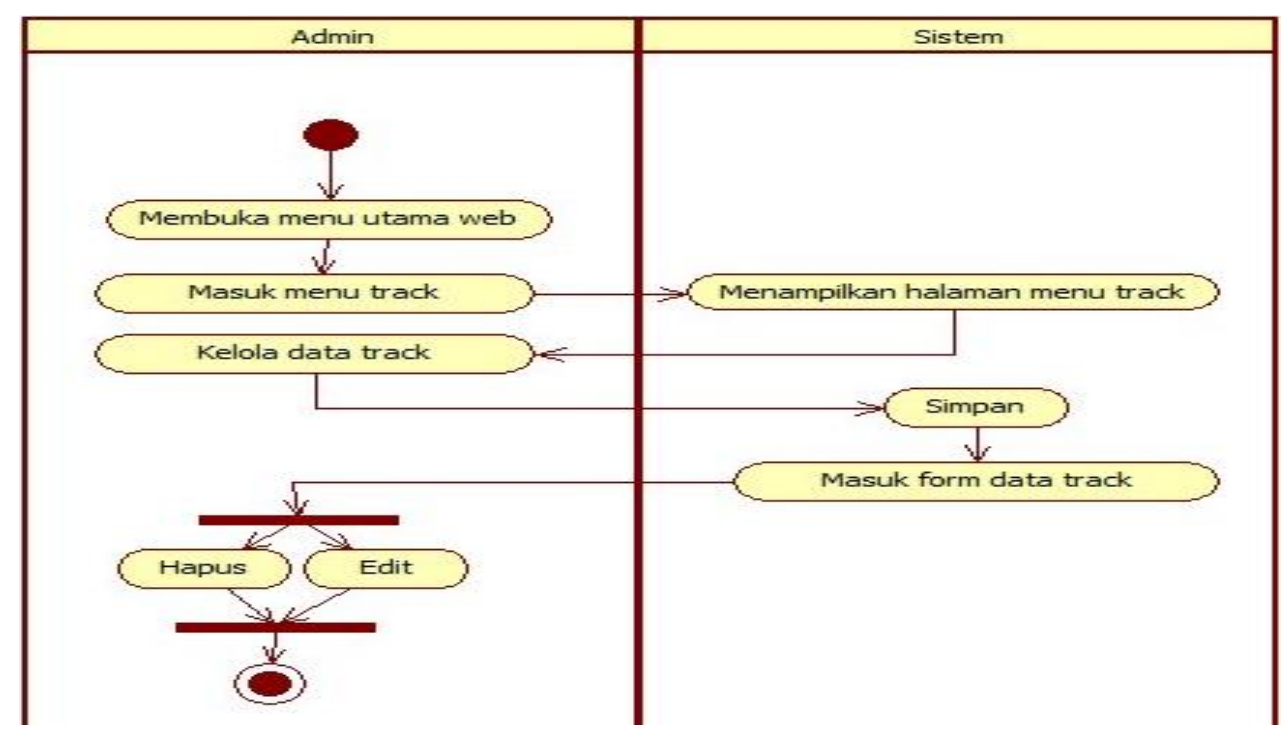

Gambar 3.3.3. Activity Diagram Kelola Track 


\subsubsection{Activity Diagram Menu \\ Transjkarta}

Berikut di bawah ini merupakan activity diagram menu transjakarta, pada activity diagram ini langkah pertama yang dilakukan user adalah membuka aplikasi Transjakarta, kemudian data akan di proses pada database. Setelah itu sistem akan menampilkan halaman menu Transjakarta.

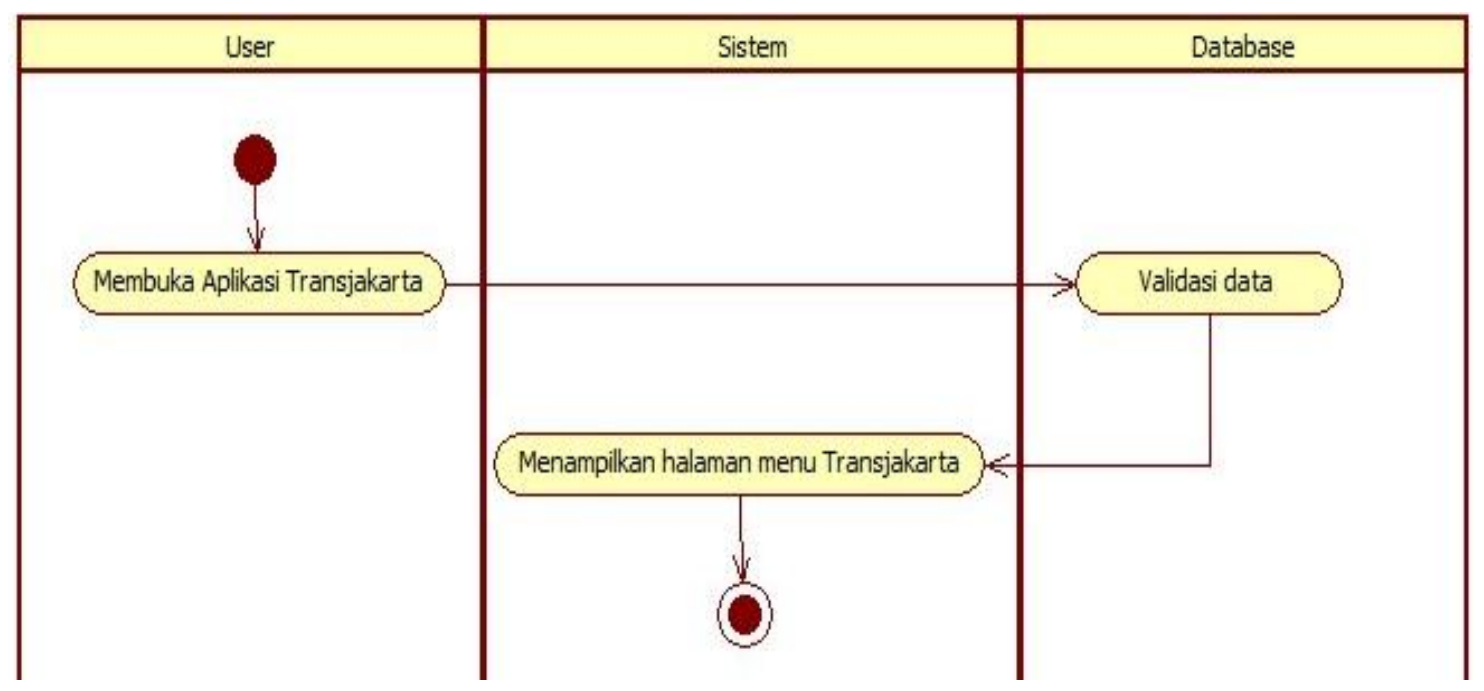

Gambar 3.3.4. Activity Diagram Menu Transjakarta

\subsubsection{Activity Diagram Menu Halte}

Berikut di bawah ini merupakan activity diagram menu halte, pada activity diagram ini langkah pertama yang di lakukan user adalah membuka aplikasi Transjakarta. Kemudian sistem akan menampilkan menu Transjakarta. Setelah itu user dapat memilih menu halte, maka data akan di validasi pada database. Setelah divalidasi data akan ditampilkan pada aplikasi.

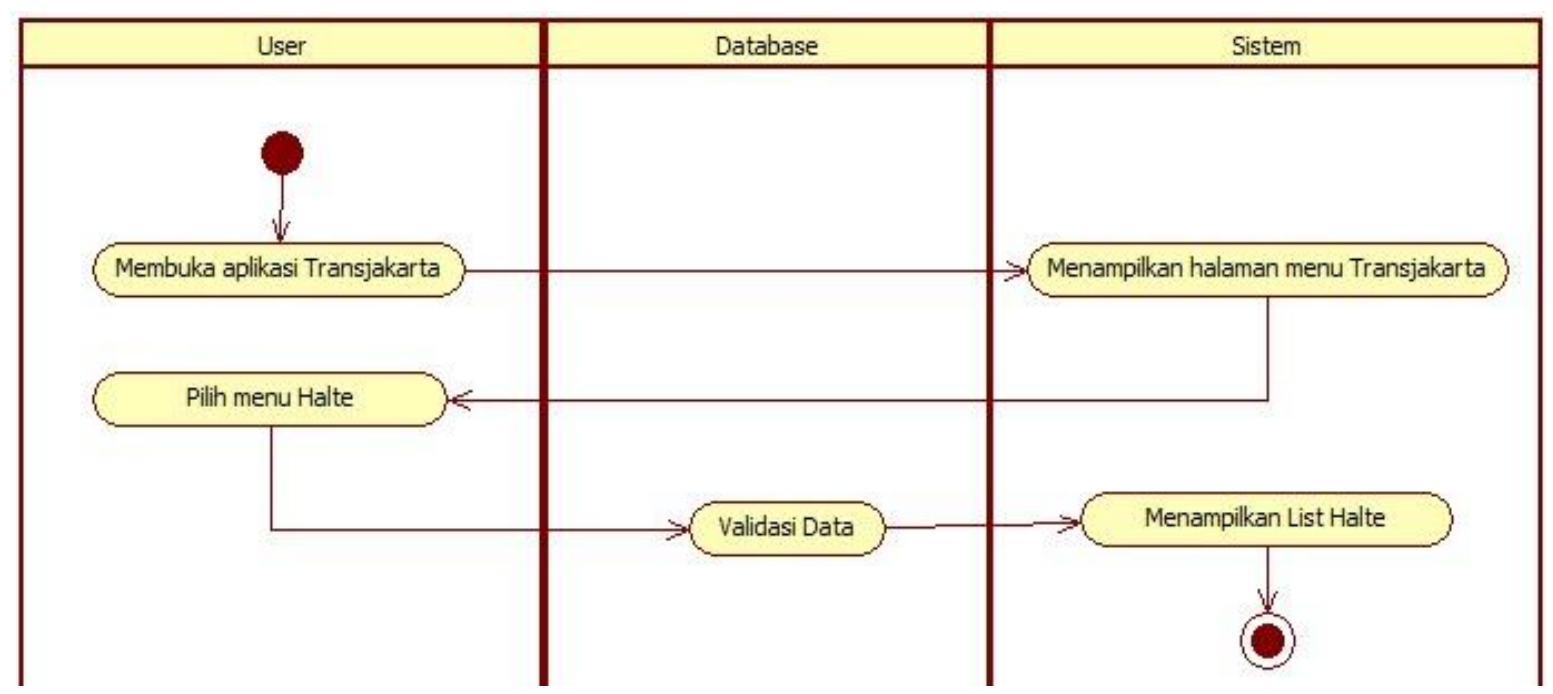

Gambar 3.3.5. Activity Diagram Menu Halte 
3.3.6. Activity Diagram List Bus dan List Tempat Tujuan

Berikut di bawah ini merupakan activity diagram list bus dan pilih list tempat tujuan, pada activity diagram ini langkah pertama yang di lakukan user adalah membuka aplikasi, setelah itu user memilih menu Transjakarta dan data akan divalidasi pada database. Setelah divalidasi data akan ditampilkan. Disini user dapat memilih alamat tujuan perjalan yang dinginkan, setelah di pilih maka data akan di validasi pada database. Setalah itu data perjalanan akan di tampilkan,tracking bus akan ditampilkan, dan bus yang beroperasi juga akan ditampilkan.

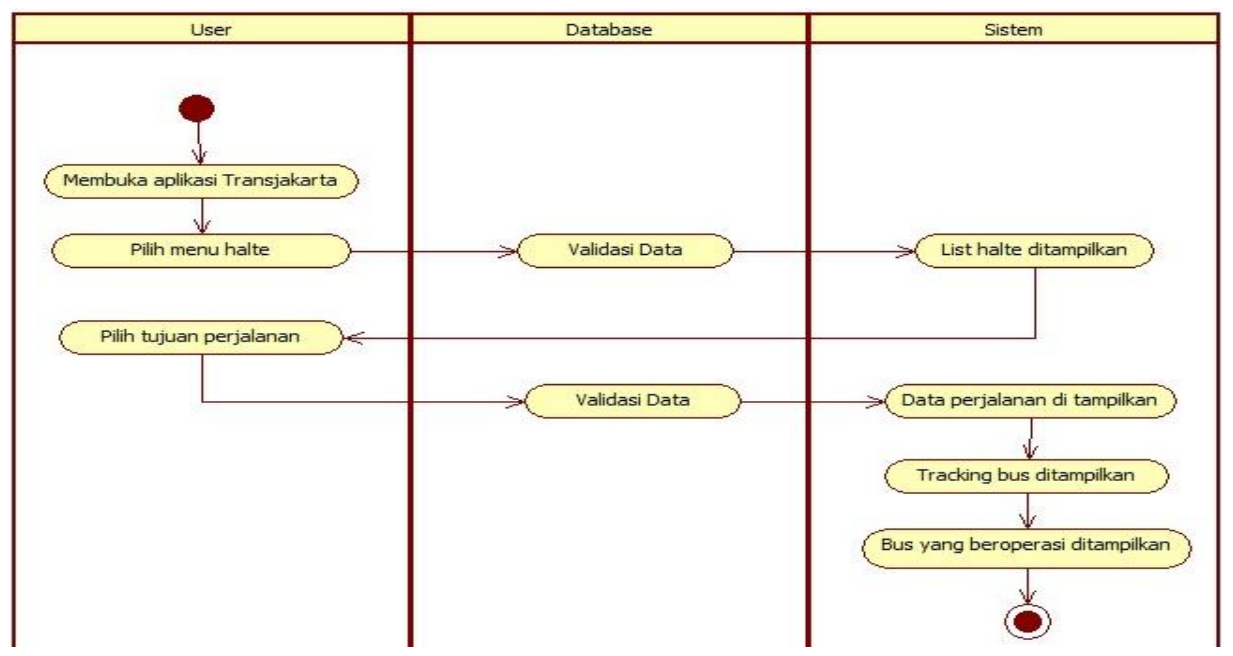

Gambar 3.3.6. Activity Diagram list bus dan list tempat tujuan

\subsubsection{Activity Diagram History Track}

Di bawah ini merupakan activity diagram history track, dimana pada activity ini langkah awal yang dilakukan user adalah membuka aplikasi kemudia memilih menu utama. Setelah itu user memilih menu history selanjutnya menu history track akan menampilkan history rute perjalan setiap bus.

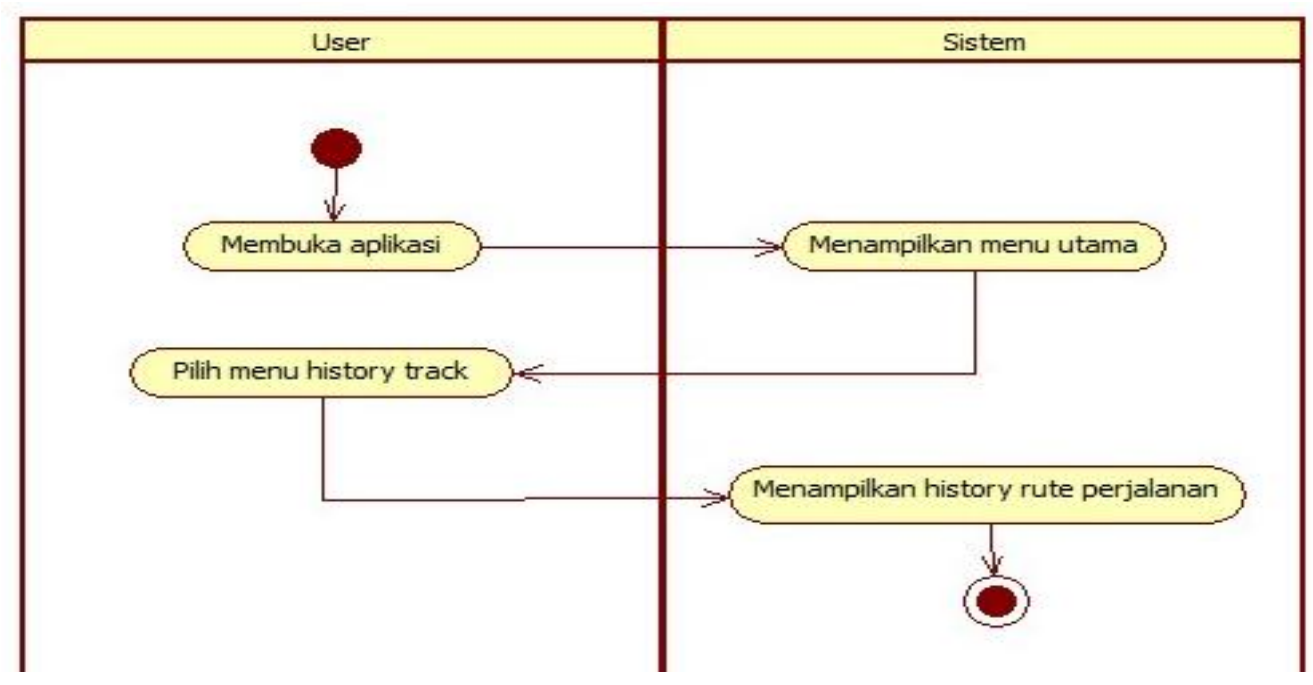

Gambar 3.3.7 Activity Diagram History Track 


\subsubsection{Sequence Diagram}

Sequence diagram merupakan suatu urutan yang menekankan pada proses pengiriman pesan yang berjalan secara dinamis. Berikut diagram pada sistem yang di usulkan.

\subsubsection{Sequence Diagram Login Admin}

Pada sequence diagram login admin di bawah ini, langkah awal yang dilakukan admin adalah melakukan login terlebih dahulu. Jika sudah login admin memasukkan username dan password, dan jika username dan password yang di input benar maka akan masuk ke database web browser.

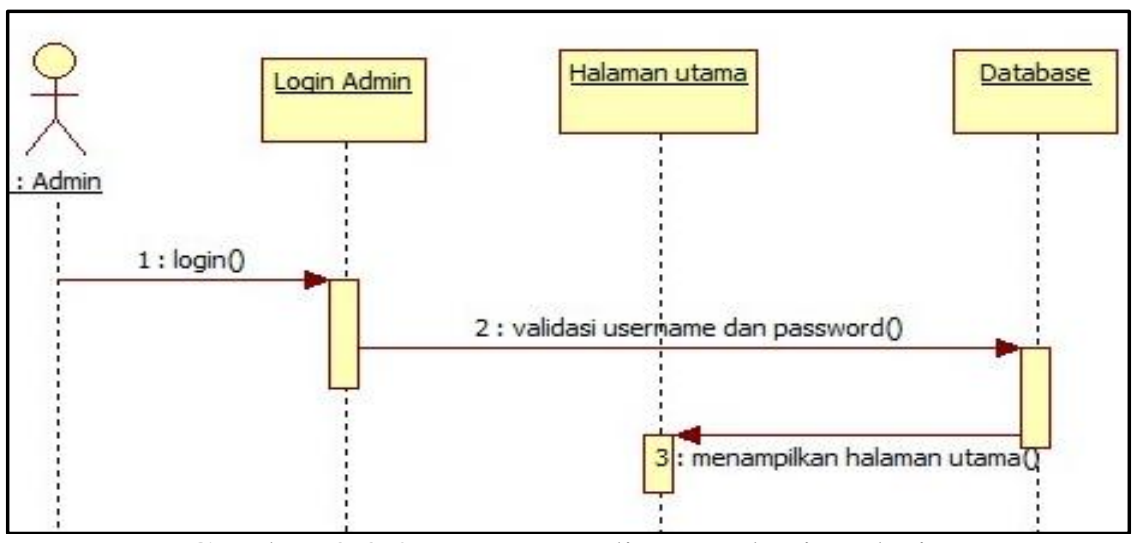

Gambar 3.3.8 Sequence diagram login admin

\subsubsection{Sequence Diagram Kelola Halte}

Pada activity diagram ini langkah pertama yang di lakukan Admin adalah membuka menu utama web server, kemudian masuk ke menu bus, setelah itu admin menginput from input data dan data yang sudah di input akan di simpan dan di proses pada database, kemudian admin juga bisa mengedit dan menghapus data yang sudah di input sebelumnya.

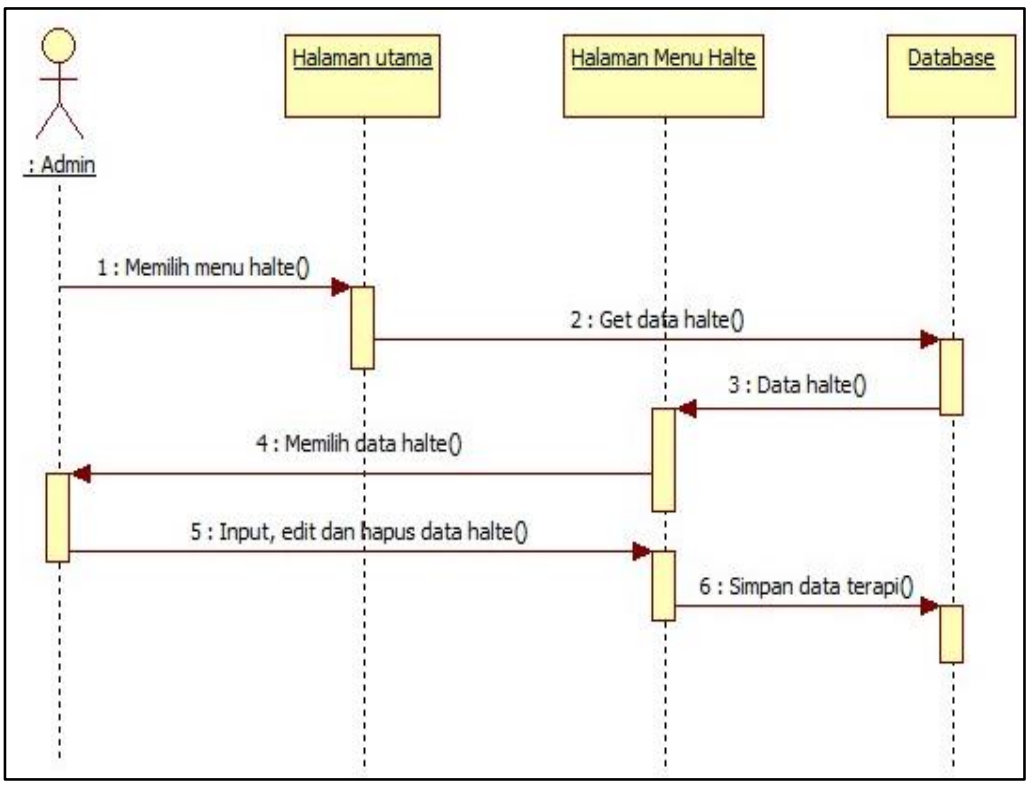

Gambar 3.3.9 Sequence diagram kelola halte 


\subsubsection{Sequence Diagram Kelola Bus}

Berikut merupakan sequance diagram kelola bus, dimana hal pertama yang dilakukan admin adalah memilih menu bus, setalah di pilih menu bus maka sistem akan memproses untuk menampilkan halaman utama menu bus, maka data-data menu bus akan ditampilkan. Dan admin dapat memilih data bus untuk dapat menginput atau mengedit bahkan menghapus data menu bus. Setelah itu data akan tersimpan pada database.

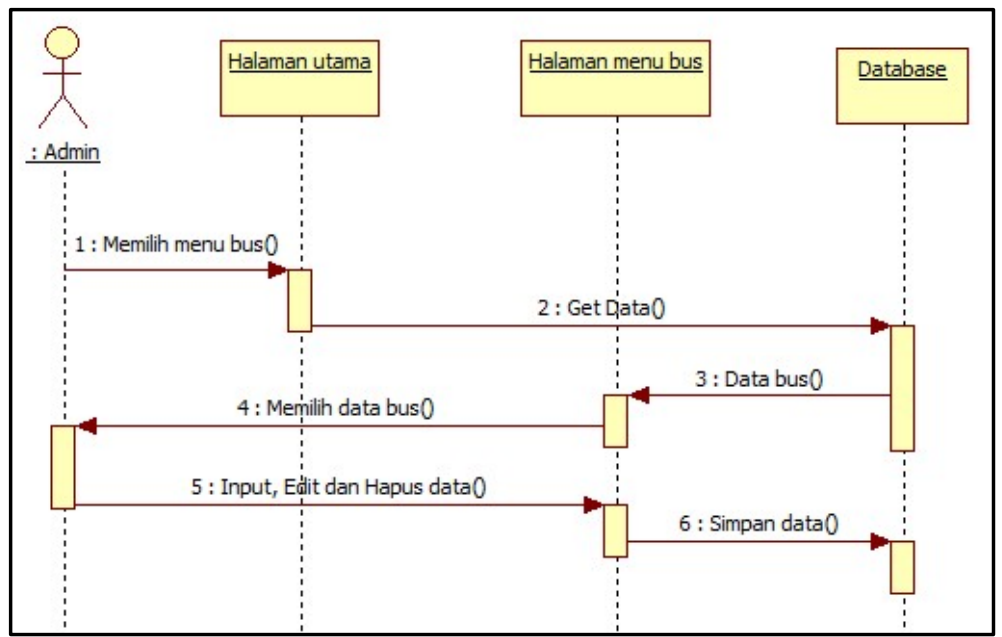

Gambar 3.3.10 Sequence Diagram Kalola Bus

\subsubsection{Sequence Diagram Kelola Track}

Berikut merupakan sequance diagram kelola track, dimana hal pertama yang dilakukan admin adalah memilih menu track, setalah di pilih menu bus maka sistem akan memproses untuk menampilkan halaman utama menu bus, maka data-data menu bus akan ditampilkan. Dan admin dapat memilih data bus untuk dapat menginput atau mengedit bahkan menghapus data menu bus. Setelah itu data akan tersimpan pada database.

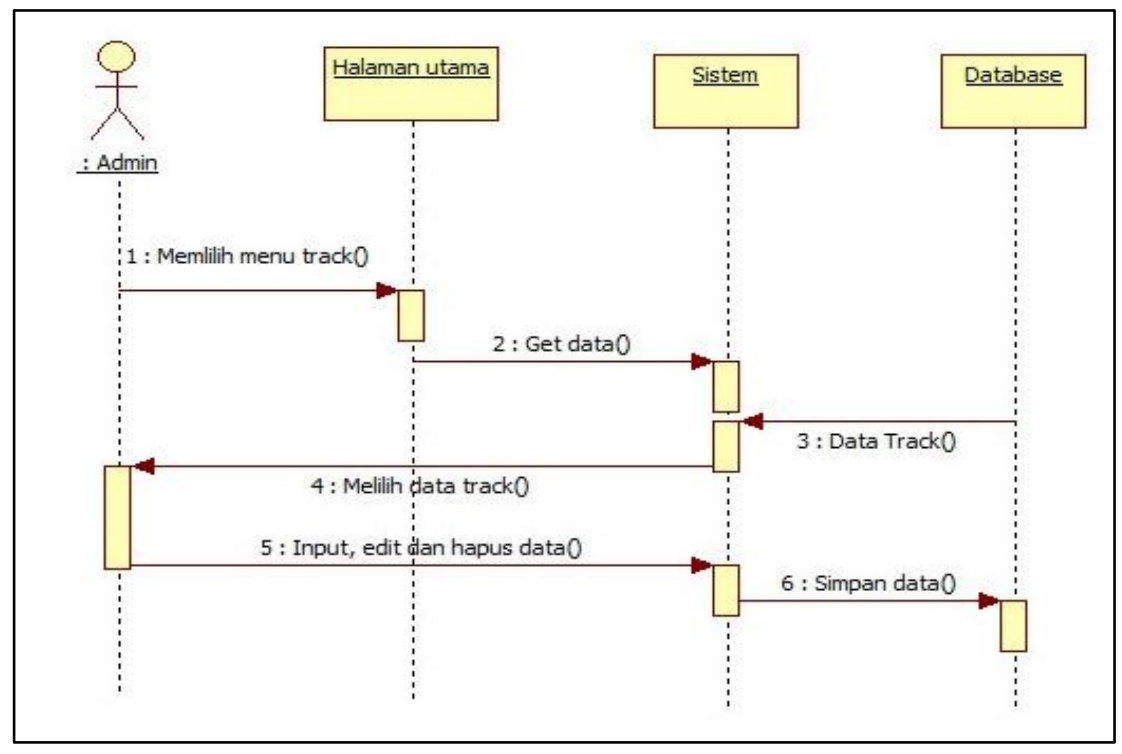

Gambar 3.3.11 Sequence diagram kalola track 


\subsubsection{Sequence Diagram Menu \\ Transjakarta}

Pada sequence diagram di bawah ini langkah awal yang dilakukan user adalah membuka aplikasi Transjakarta, kemudian data akan divalidasi setelah itu data akan ditampilkan pada aplikasi Transjakarta.

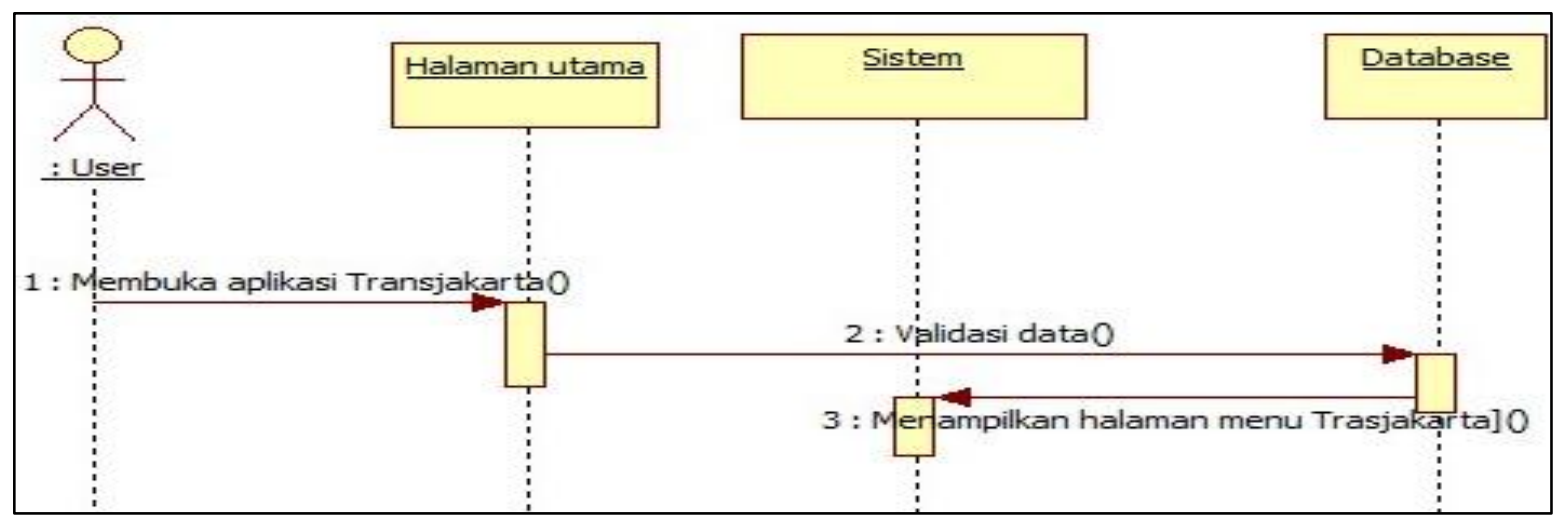

Gambar 3.3.12 Sequence diagram menu Transjakarta

\subsubsection{Sequence Diagram Menu Halte}

Pada sequence diagram menu halte di bawah ini, langkah awal yang dilakukan user adalah membuka aplikasi Transjakarta.
Kemudian data akan ditampilkan. Setelah itu user memilih menu halte, setelah itu data akan di validasi pada database. Dan data sistem akan menampilkan list halte.

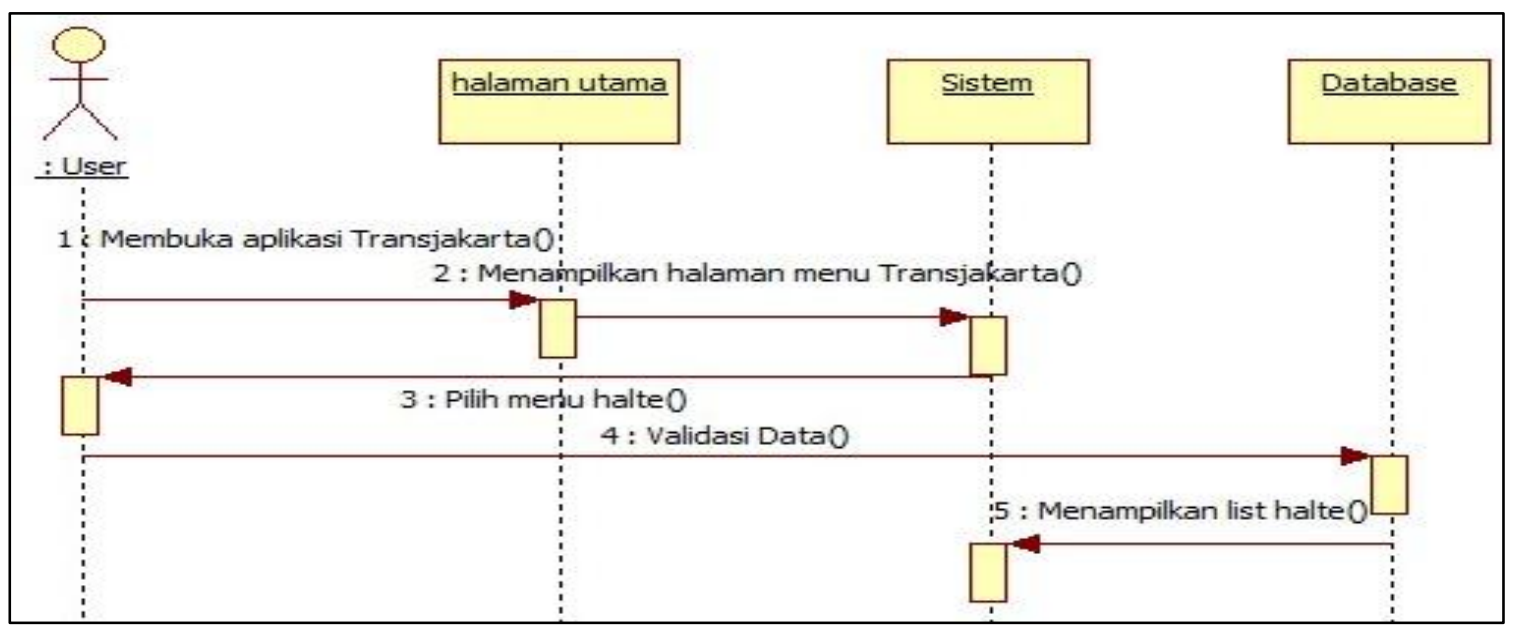

Gambar 3.3.13 Sequence Diagram Menu Halte

\subsubsection{Sequence Diagram List Bus dan List Tempat Tujuan}

Pada sequence diagram di bawah ini, langkah awal yang dilakukan user adalah memilih menu pada aplikasi kemudian pilih menu rute perjalanan. Setelah itu data akan di tampilkan oleh sistem, setelah memilih rute perjalanan disana user dapat melihat daftar bus, track dan bus yang telah beroperasi. 


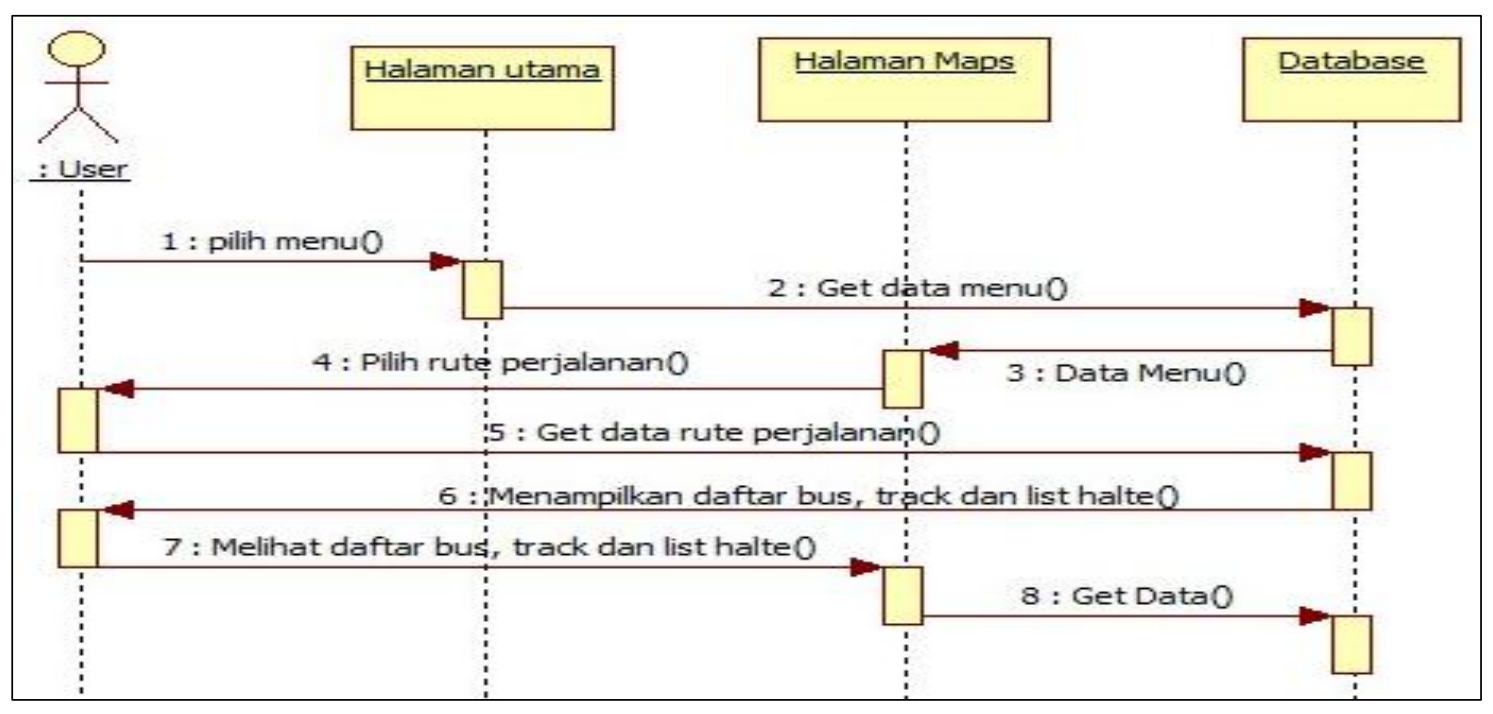

Gambar 3.3.14 Sequence Diagram List Bus dan List Tempat Tujuan

3.3.16 Sequence Diagram History Track

Pada sequence diagram dibawah ini, langkah awal yang dilakukan user adalah membuka aplikasi. Kemudian user memilih menu track, dan data menu track akan ditampilkan. Disana user dapat melihat hostory semua perjalanan bus yang beroperasi.

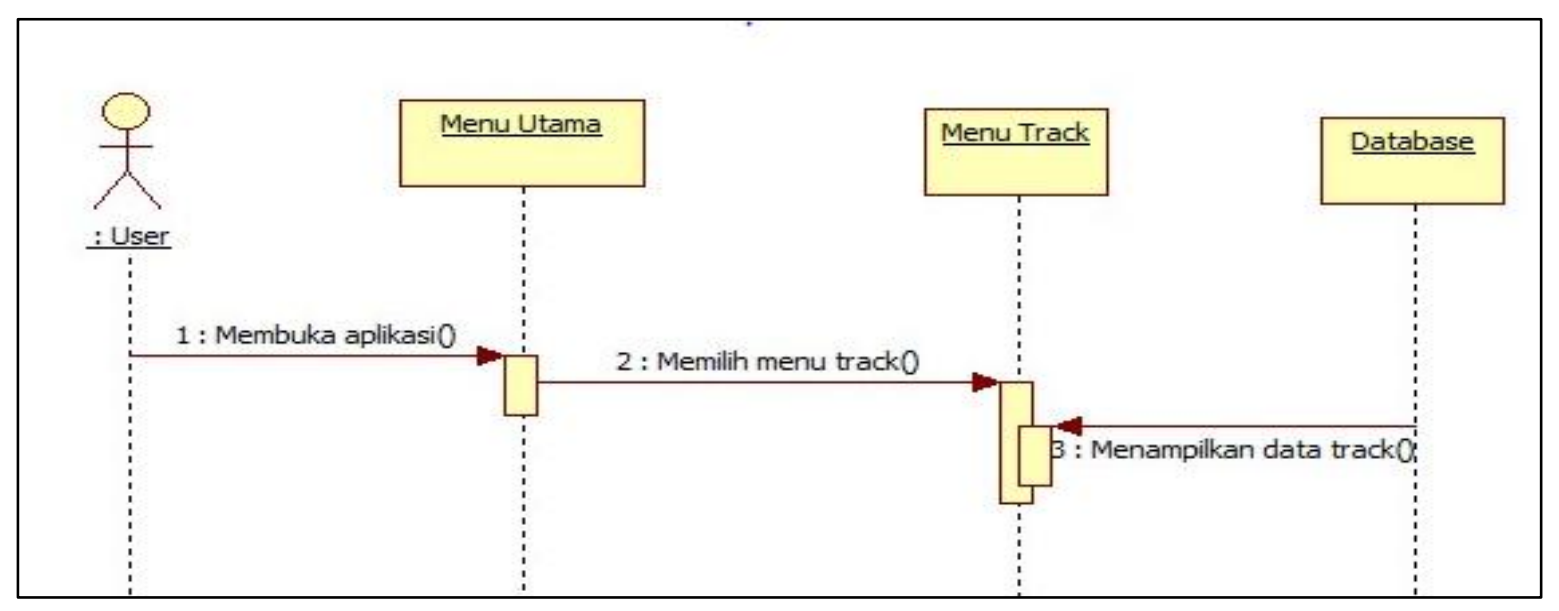

Gambar 3.3.15 Sequence diagram History Track

\subsection{Class Diagram}

Di bawah ini merupakan class diagram yang mencakup data-data tabel yang digunakan pada database web browser. Disini semua database sudah terhubung satu sama lain. 


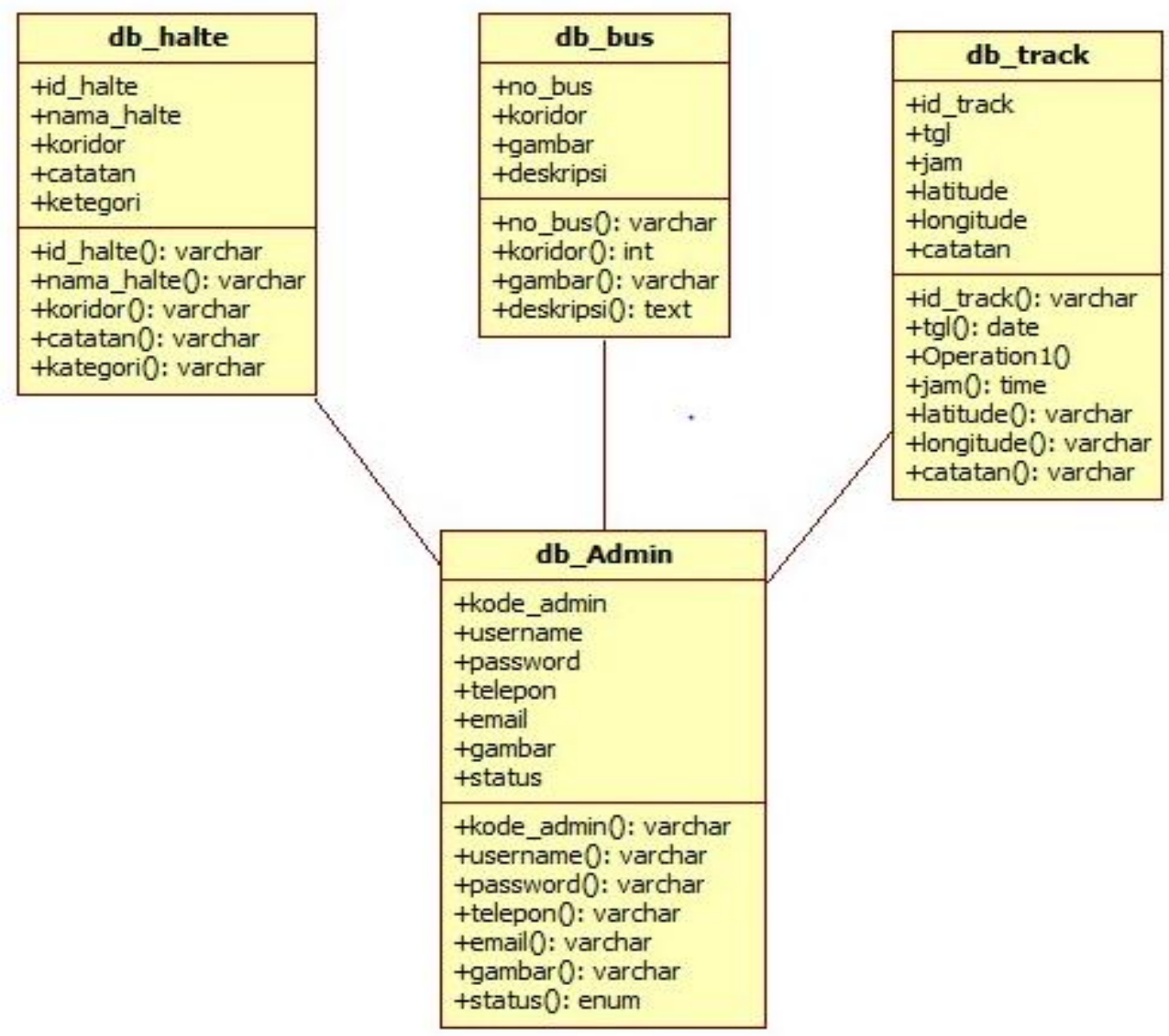

Gambar 3.4.1 Class diagram

\subsection{Metode Pengembangan Sistem}

Tahapan pengembangan sistem merupakan cara untuk mengembangkan sistem dan aplikasi baru/ sistem. Ada beberapa langkah yang menjadi tahapan proses pengembangan sistem yang disebut dengan metode.

Dalam penelitian ini memiliki tujuan mengembangkan sistem penyampaian informasi yang lebih menarik dan efisien. Metode pengembangan yang digunakan adalah Metode Rapid Application Development (RAD).

Metode ini terdiri dari enam tahapan, yaitu:

a. Pemodelan Bisnis
Tahapan untuk mengumpulkan kebutuhan informasi yang terkait dalam penelitian ini.

b. Pemodelan Data

Tahapan mengumpukan data yang terkait dengan informasi yang sudah dikumpulkan dan menjadikan data yang dikumpulkan menjadi informasi.

c. Pemodelan Proses

Menerapkan informasi dan data yang sudah didapatkan untuk diproses menjadi satu informasi yang siap untuk diimplementasikan.

d. Pembuatan Aplikasi

Tahapan ini adalah tahap selanjutnya untuk membuat sebuah sisttem yang diusulkan berdasarkan informasi yang 
sudah diproses dari pengumpulan informasi dan data.

e. Pengujian dan Pergantian

Tahapan ini adalah tahapan untuk pengujian padaa sistem yang diusulkan, jika semua sudah teruji maka tahapan pengembangan sistem selesai.

\subsection{Tampilan Antar Muka}

3.61. Tampilan Antarmuka Menu Admin

Gambar di bawah adalah antarmuka halaman admin. Data yang ditampilkan, yaitu kode admin, username, email, telepon, gambar. Halaman admin dapat digunakan admin untuk mengelola data admin, yaitu menambah, mengedit, dan menghapus data pengguna. Admin dapat mengakses halaman tersebut dengan memilih menu "admin".

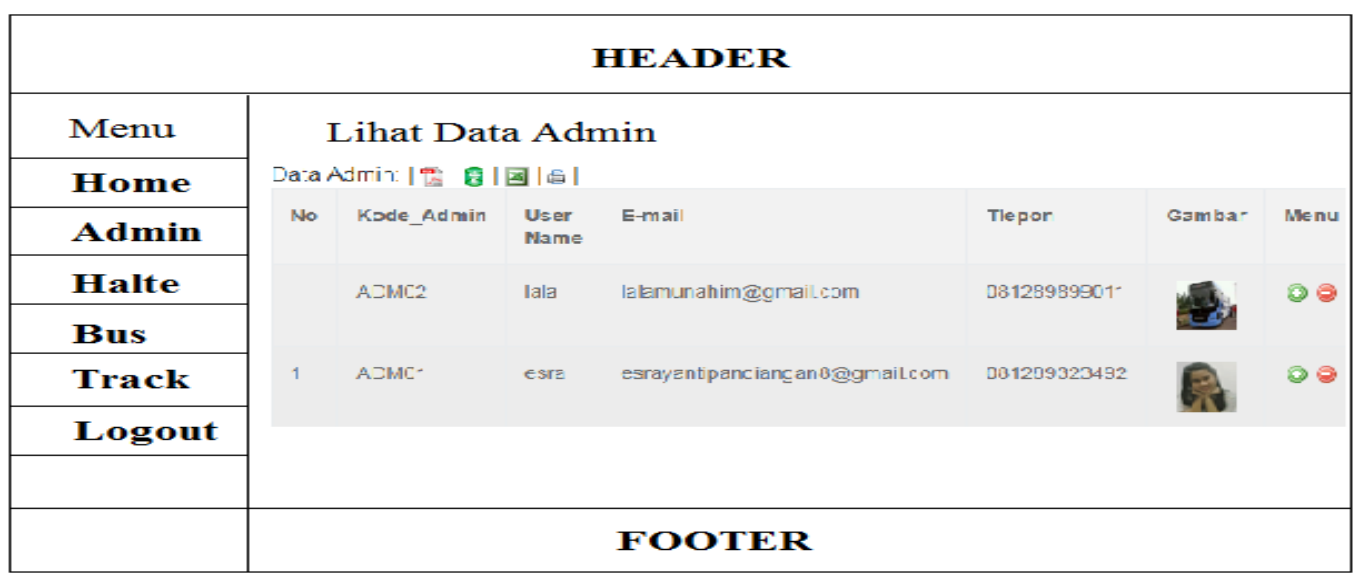

Gambar 3.6.1 Tampilan Antarmuka Menu Admin

3.6.2 Tampilan Antarmuka Form Input Data Halte

Admin dapat mengakses halaman dengan mengklik menu "Halte" pada halaman utama web admin. Halaman halte dapat digunakan untuk menambah data keterangan halte. Setelah meng-input data, admin mengklik tombol "simpan" agar data halte tersimpan ke database.

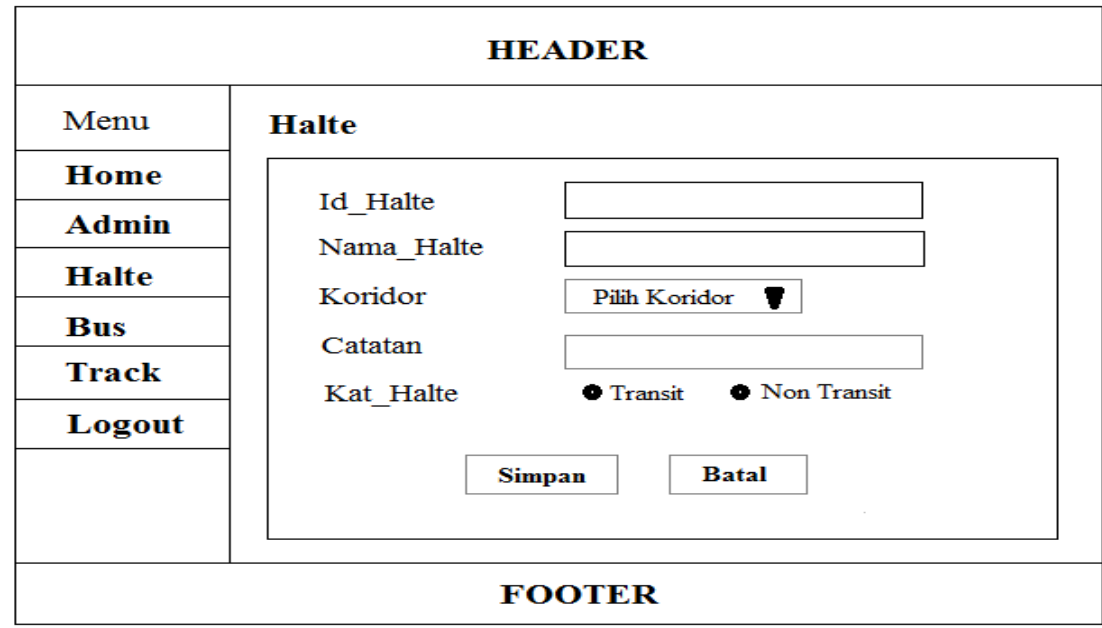

Gambar 3.6.2 Tampilan Antarmuka Form Data Halte 


\subsubsection{Tampilan Antarmuka Menu Halte}

Gambar di bawah adalah antarmuka halaman halte. Data yang ditampilkan, yaitu kode halte, nama halte, kategori transit, dan catatan. Halaman halte dapat digunakan admin untuk mengelola data halte, yaitu menambah, mengedit, dan menghapus data halte. Admin dapat mengakses halaman tersebut dengan memilih menu "halte" pada web admin.

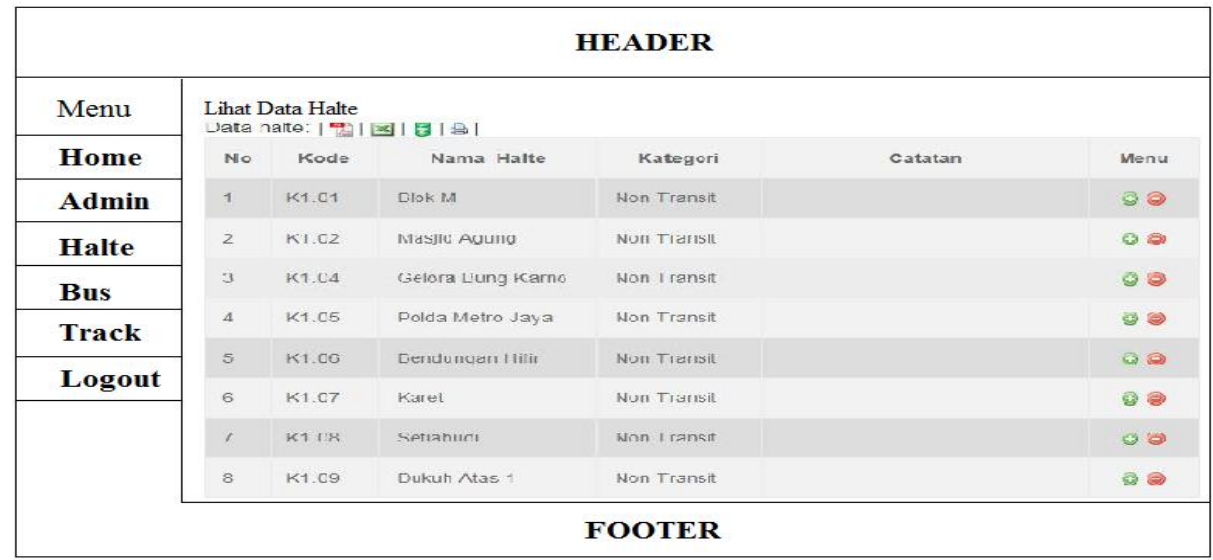

Gambar 3.6.3 Tampilan Antarmuka Menu Halte

3.64.Tampilan Antarmuka Form Input Data Bus

Admin dapat mengakses halaman bus dengan mengklik menu "Bus" pada halaman utama web admin. Halaman bus dapat digunakan untuk menambah data keterangan bus. Setelah meng-input data, admin mengklik tombol "simpan" agar data bus tersimpan ke database.

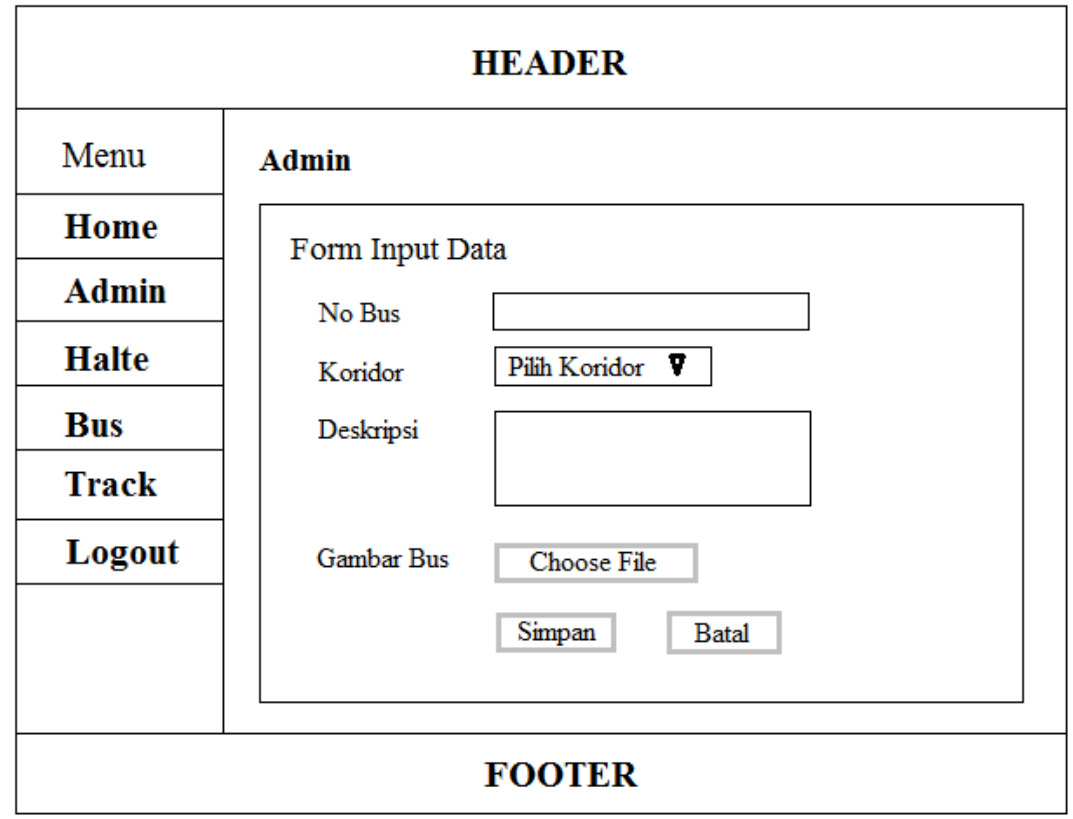

Gambar 3.6.4 Tampilan Antarmuka Menu Halte 
Tampilan Antarmuka Login Driver Bus

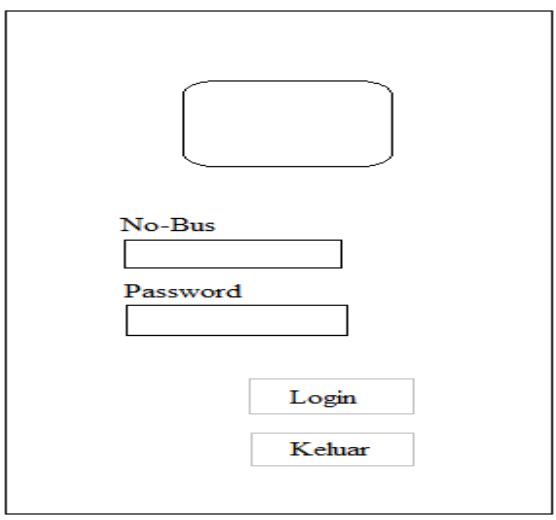

Gambar 3.6.5 Tampilan Antarmuka Login Driver Bus

\section{Tampilan Antarmuka List Rute TransJakarta}

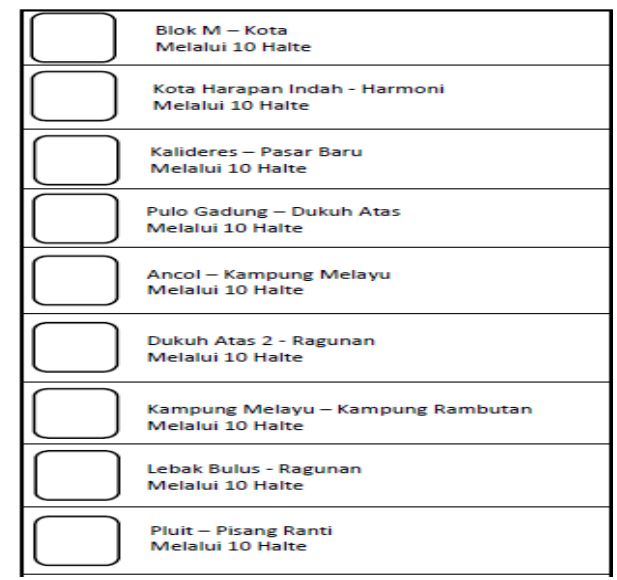

Gambar 3.6.6 Tampilan Antarmuka List Rute Transjakarta

\section{Kesimpulan}

\subsection{Kesimpulan}

Berdasarkan hasil pembuatan laporan Sistem Informasi Rute Bus Transjakarta dengaan metode RAD ( Rapid Application Development ) berbasis android untuk memudahkan masyarakat dalam meningkatkan sistem pelayanan, maka dapat diambil kesimpulan sebagai berikut:

1. Sistem informasi yang telah dibuat ini dapat membantu pengguna bus untuk mengetahui letak dan jadwal pemberangkatan bus.

2. Sistem dapat memonitoring kilometer bus dan pencatatan jadwal masuk bus pada setiap halte.

\subsection{Saran}

1. Sistem ini dapat dikembangkan lebih inovatif dan kreatif, agar tampilan pada aplikasi ini terlihat menarik pada para pengguna.

2. Diharapkan penambahan rute yang terbaru pada pengembangan selanjutnya dan penambahan fitur dalam meng-update informasi terbaru.

V. Daftar Pustaka

Alfa Satyaputra, M., \& Eva Mauliana Aritonang, S. (2014). Beginning Android Programming with ADT Bundle. Jakarta: Alex Media Computindo.

Syashasta Fransiscus Xaverius and Hansun Seng,(2016). Rancang Bangun Aplikasi Informasi Rute Bus Mayasari Bakkti dengan Algoritma Knuth-Morris-Pratt Berbasis Android. Jurnal Informatika, Vol 12, No. 1

Ariyandi Deby.(2016) Aplikasi Pencarian Rute Angkutan Umum di Bandar Lampung Berbasis Mobile Android. Diambil dari http://digilib.unila.ac.id/ 22984/3/SKRIPSI\%20TANPA\%20B AB\%20PEMBAHASAN.pdf

Harahap, N. S. (2015). ANDROID Pemrograman Aplikasi Mobile Smartphone. Bandung: Informatika.

Hariyanto, B. (2014). Esensi - Esensi Bahasa Pemrograman Java. Bandung: INFORMATIKA. 
Satyaputra, A., \& Aritonang, E. M. (2014). Beginning Android Programming with ADT Bundle. Jakarta: Alex Media Computindo.

MADCOMS. (2016). Pemrograman PHP dan MySQL. Yogyakarta: ANDI.

Andi. (2010). Kupas Tuntas Adobe Dreamweaver CS5 dengan Pemrograman PHP \& MySQL. Yogyakarta: C.V.Andi Offset.

Zulfikar Yusya Mubarak, E. N. (2017). PERANCANGAN SISTEM

\begin{tabular}{crr} 
KESEHATAN & DI & TINGKAT \\
POSYANDU & \multicolumn{2}{c}{ CILACAP } \\
SELATAN & \multicolumn{2}{c}{ KABUPATEN } \\
CILACAP. & Seminar & Nasional \\
Teknologi & Informasi & dan \\
Multimedia & $2017,2$. &
\end{tabular}

Sukamto, R.A.,\& Shahaluddin, M.(2014). Rekayasa Perangkat Lunak. Bandung: Informatika Bandung. INFORMASI 